\title{
M-ASSOCIATED PROTEIN ANTIBODIES IN PATIENTS WITH RHEUMATIC FEVER
}

\author{
Diana R. Martin and Kristina J. Dick
}

Streptococcus Reference Laboratory, National Health Institute, PO Box 50-348, Porirua, Wellington, New Zealand

\begin{abstract}
Summary. Sequential serum samples obtained from 50 rheumatic fever subjects and from control individuals matched for time, age and geographical location were tested for antibodies against the $\mathrm{M}$-associated protein antigens, MAP I and MAP II. Antibody titres were determined by the complement fixation test with a partially-purified extract of Streptococcus pyogenes serotype M30 as the MAP I antigen and an acid extract of serotype M48 as the MAP II antigen. Titres of MAP I antibody exceeded those of MAP II antibody in all but six rheumatic fever subjects. Anti-MAP I titres in excess of 40 were significantly more common in rheumatic fever subjects than in matched controls $(\mathrm{p}<0.001)$ or matched subjects with a diagnosis of acute post-streptococcal glomerulonephritis $(\mathrm{p}<0.01)$. Peak MAP I titres were present at the time of admission to hospital in the sera of 40 of the 50 rheumatic fever subjects. In the remainder peak titres occurred within 10 days. Antibody titres were maintained for a mean of $10 \cdot 3$ weeks before declining. Changes in MAP antibody titres were independent of changes in antistreptolysin $\mathrm{O}$ and anti-DNAase $\mathrm{B}$ titres. Normal children aged between 6 and 15 had higher MAP antibody titres than 2-5-year-old children. Rheumatic fever subjects had significantly higher mean titres of MAP I antibody than matched controls in each age group.
\end{abstract}

\section{INTRODUCTION}

Group A streptococci possess non-type-specific antigens closely associated with the type-specific determinants of M protein (Vosti, Johnson and Dillon, 1971; Widdowson, Maxted and Pinney, 1971; Beachey, Ofek and Bisno, 1973). These M-associated protein (MAP) antigens have been divided into at least two closely related antigenic types, designated I and II (Widdowson, Maxted and Pinney, 1976). A relationship between the MAP antigen type and other characteristics that serve to divide group A streptococci into categories has been shown (Widdowson et al., 1974 and 1976). Opacity factor-negative serotypes associated with outbreaks of upper respiratory tract

Received 1 Aug. 1983; accepted 14 Oct. 1983 
infection possess the MAP I antigen, whereas opacity factor-positive serotypes associated with skin infections often possess the MAP II antigen.

Antibodies to MAP antigens are elicited at the time of infection. Studies by Widdowson et al. (1976) suggest that development of antibody depends upon the type of MAP antigen possessed by the invading serotype. They showed that MAP titres were invariably low after infection with opacity factor-positive serotypes whereas the response to opacity factor-negative serotypes varied: infection with certain opacity factor-negative serotypes always elicited a vigorous anti-MAP response but anti-MAP titres were consistently low after infection with others.

A striking feature of these early studies was the demonstration that rheumatic fever patients invariably had high anti-MAP I titres (Widdowson et al., 1971). A similar observation was reported by Beachey et al. (1973) who showed that antibody to purified preparations of non-type-specific $M$ protein was consistently high in rheumatic fever subjects. In both studies a semi-purified preparation of protein M30 was used as antigen in a complement fixation test and presumably a similar, or identical antibody was being measured.

We have studied titres of MAP antibodies in sera of rheumatic fever subjects in New Zealand as part of a prospective study to determine whether rheumatogenicity was confined to opacity factor-negative serotypes that possess the MAP I antigen. Widdowson et al. (1976) have reported the relationship of serotype to antibody formation but no information has been published about the maintenance of antibody titres. A retrospective study of type-specific $M$ antibody in rheumatic fever subjects and matched controls provided material for a parallel study of MAP antibodies in these subjects.

\section{MATERIALS AND METHODS}

Rheumatic fever subjects. Serum was obtained from 50 subjects in whom the diagnosis of rheumatic fever was confirmed by the attending physician. Acute and convalescent serum samples were used. Subjects were from various geographical areas in the North Island, New Zealand.

Matched controls. Serum from control subjects without any history of rheumatic fever was obtained from individuals in hospital or attending out-patient departments who were matched for age, time, geographical location and, where possible, sex and race.

Acute glomerulonephritis subjects. Serum was obtained from individuals in whom a diagnosis of acute post-streptococcal glomerulonephritis had been made and who could be matched in time, geographical location and age with a rheumatic fever subject.

All serum samples from rheumatic fever, control and acute glomerulonephritis subjects were stored without preservative at $-20^{\circ} \mathrm{C}$ until tested. The number of serum samples obtained from each subject varied.

Normal children. Sera submitted for streptococcal antibody determinations, in which neither antistreptolysin O (ASO) nor anti-DNAase B levels were elevated above the upper limits of normal, were used. Upper limits of normal were taken as 141 units (ASO) and 120 units (anti-DNAase B) for the 2-5 age group, and 282 units (ASO) and 400 units (anti-DNAase B) for the 6-10 and 11-15 age groups. These values were determined with sera from children with no known streptococcal infection, sampled from the same population areas as the rheumatic fever subjects. The upper limit for an antibody is defined as that limit not exceeded by more than $20 \%$ of a normal population (Wannamaker and Ayoub, 1960). Upper limits used in this study were the same as those reported previously (Dawson and Martin, 1982) except for the anti-DNAase B level for 11-14 year olds, for whom a lower value was used in the present study.

Anti-MAP determination. The complement fixation test described by Widdowson et al. 
(1971) was used. The MAP I antigen was prepared from an acid extract of a strain of Streptococcus pyogenes, serotype M30 (Str $\mathrm{A}_{30} 29 / 59$; Czechoslovak NCTC) partially purified by precipitation with ammonium sulphate at a concentration of between 30 and $60 \%$ (Widdowson et al., 1971). Map II antigen was an acid extract of the serotype M48 reference strain of $S$. pyogenes (Str $\mathrm{A}_{48}$ 18/59; Czechoslovak NCTC) which has no detectable $\mathrm{R}$ antigen. Further purification of the MAP II antigen results in loss of activity (J. P. Widdowson, personal communication). The M30 and M48 serotypes have not yet been identified amongst New Zealand isolates of $S$. pyogenes. Sera showing anti-complementary activity were absorbed with guinea pig complement not more than twice (Widdowson et al., 1971).

ASO determinations. The method of Liao (1951), with $50 \%$ haemolysis as the end point, was used.

Anti-DNAase B titrations. The method of Nelson, Ayoub and Wannamaker (1968) was used.

\section{RESULTS}

\section{Rheumatic fever subjects}

The 50 rheumatic fever subjects were, as far as could be ascertained, independent cases seen between October 1978 and September 1982. Control individuals were strictly matched for time and geographical location. The mean age was $9 \cdot 5$ years for rheumatic fever subjects and $9 \cdot 8$ years for controls. In 18 pairs both were male. In two pairs the rheumatic fever subject was male and the control female; in seven other pairs the control was male and the subject female. Nine pairs could not be precisely matched for race. Five rheumatic fever subjects had had a previously documented episode of rheumatic fever. A further recurrence was recorded for one of these and a recurrence occurred in five other subjects.

Twenty-one cases with a diagnosis of acute post-streptococcal glomerulonephritis could be matched with a rheumatic fever subject for geographical location, age and time. The mean age was 8.3 years for glomerulonephritis and 8.7 years for the matched rheumatic fever subjects.

\section{Anti-MAP titres in rheumatic fever subjects}

Peak titres of anti-MAP I antibodies in the serum of 44 of the 50 rheumatic fever subjects were higher than those of MAP II antibodies (fig. 1). Of the six exceptions, three had the same titre for both antibodies; the other three had a titre of anti-MAP II in excess of that for anti-MAP I. The subject for whom an anti-MAP II titre of 160 was recorded and for whom no antibody to MAP I was detected (fig. 1) had experienced an upper respiratory tract infection with $S$. pyogenes of M-type 4 before his rheumatic fever. M-type 4 has the MAP II antigen (Widdowson, 1980). Of the 50 subjects studied, $34(68 \%)$ had MAP I titres $>40$, whereas only two $(4 \%)$ had MAP II titres $>40$.

Titres recorded on admission to hospital did not rise further in subsequent serum specimens from 40 of the 50 subjects. Anti-MAP I antibody titres increased in the other subjects within 10 days of admission. For nine of these 10 subjects, increases in ASO or anti-DNAase B titres, or both, also occurred, although in seven the difference was $<0 \cdot 2 \log$ dilution. In six subjects the anti-MAP I titre rose only by a factor of two. 


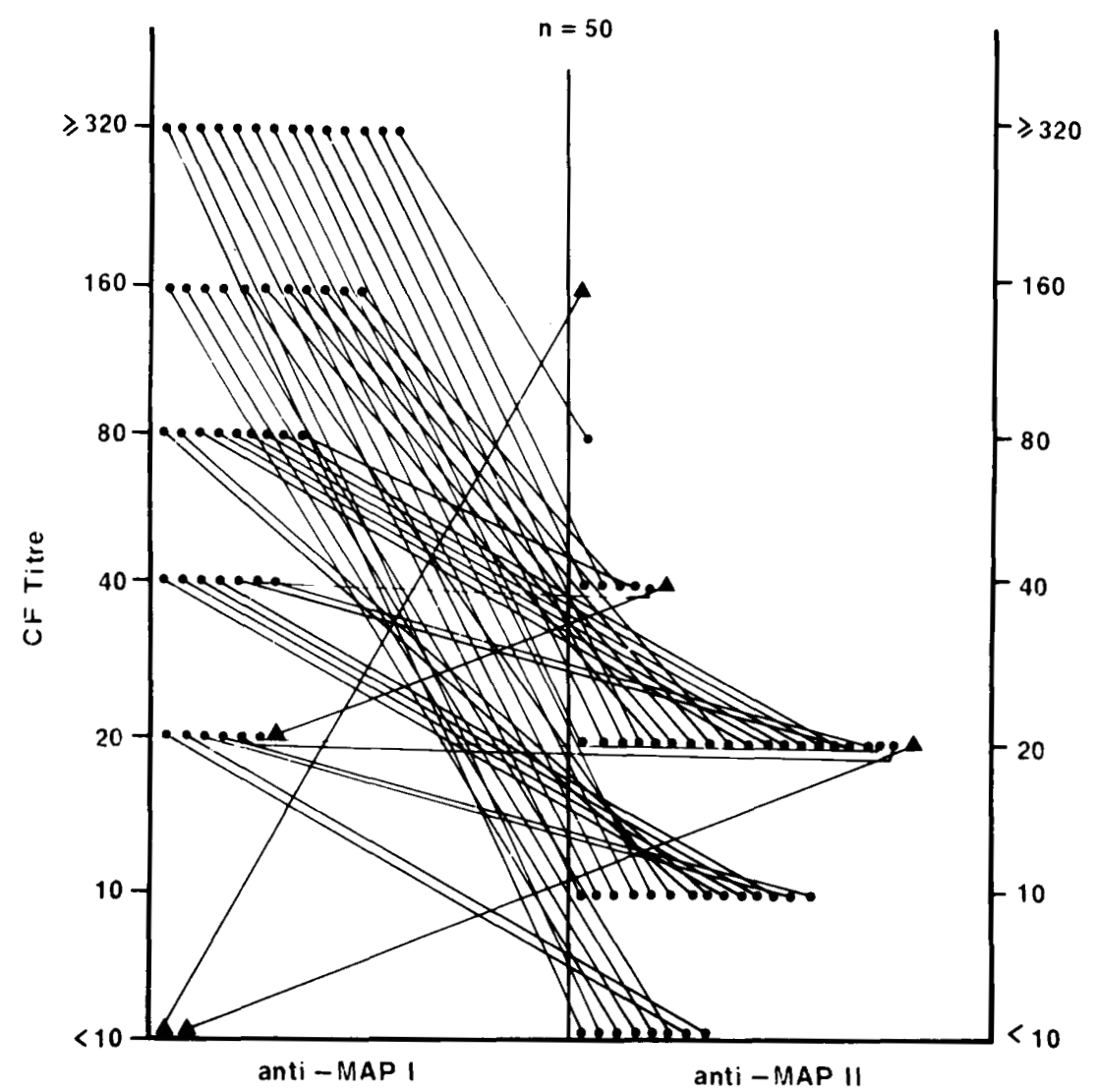

FIG. 1.-Comparison of peak titres of anti-MAP I and anti-MAP II for each rheumatic fever subject. (Complement fixation test).

In all cases, stability of the increased titres in subsequent serum samples was taken to indicate a true change rather than experimental variation.

Sufficient follow-up serum samples for the continuing observation of titres were obtained from 29 subjects. Anti-MAP titres remained elevated for varied periods before declining. A fall in anti-MAP I titre was usually paralleled by a fall in anti-MAP II titre where this was raised. No decrease of anti-MAP I titre was observed during follow-up sampling of 10 subjects although a $\geqslant 0.2 \log$ dilution fall in ASO or anti-DNAase B titre, or both, was observed in seven of them (table I). One subject maintained an anti-MAP I titre of 80 for 17 weeks, and another a titre of $\geqslant 320$ for 20 weeks. Only seven of the 29 subjects showed a fourfold or greater decrease in anti-MAP I titre during the period of follow-up. Five of these seven individuals also exhibited $a \geqslant 0.2 \log$ decrease in antibody levels to extracellular antigens (table I). Thus 16 of the 21 subjects $(76.2 \%$ ) for whom a $\geqslant 0.2 \log$ fall in ASO or anti-DNAase B titre, or both, was recorded did not exhibit a fourfold decrease in anti-MAP I titre; however, in nine subjects a twofold decrease in titre was recorded. The mean duration of time 
TABLE 1

Changes in MAP I antibody titres in relation to changes in titres of other streptococcal antibodies ( $A S O$ and anti-DNAase B) observed in follow-up sera of 29 rheumatic fever subjects

\begin{tabular}{l|cc}
\hline $\begin{array}{l}\text { Change in } \\
\text { anti-MAP I } \\
\text { titre }\end{array}$ & $\begin{array}{c}\text { Number of subjects with decrease in } \\
\text { ASO or anti-DNAase B or both }\end{array}$ \\
\cline { 2 - 3 } $\begin{array}{l}\geqslant 0 \cdot 2 \log \\
\text { decrease }\end{array}$ & $\begin{array}{c}<0 \cdot 2 \log \\
\text { decrease }\end{array}$ \\
\hline $\begin{array}{l}\text { None } \\
\text { decrease }\end{array}$ & 7 & 3 \\
$\begin{array}{l}\text { Fourfold or } \\
\text { greater decrease }\end{array}$ & 9 & 3 \\
Total & 5 & 2 \\
\hline
\end{tabular}

elapsing before a change in titre was observed was 9.6 weeks for subjects displaying a twofold drop in titre and $10 \cdot 3$ weeks for those showing a fourfold decrease. The MAP-antibody titres fell to very low levels during the period of sampling in four subjects who showed no evidence of intercurrent infection.

\section{Case reports}

Patient A reported to her general practitioner complaining of joint pains, and was admitted to hospital for investigation. A throat swab taken at this time revealed a group A streptococcus (T11, M untypable, opacity factor-positive). Streptococcal antibody titres (ASO 110 units, anti-DNAase B 120 units) were not elevated. Four weeks later the patient was readmitted to hospital with a diagnosis of rheumatic fever. On re-admission, serum antibody titres were markedly elevated (ASO 880 units, anti-DNAase B 1600 units). Concurrently, the anti-MAP I titre rose from 40 to 160. Eight weeks later this titre had fallen to 80 and it remained at that level in the final sample tested after 16 weeks. Decreases in ASO and anti-DNAase B titres exceeding a $0.2 \mathrm{log}$ difference were not demonstrated during the period of sampling. The serological results are shown in fig. 2.

Patient $B$ was a child receiving prophylactic benzathine penicillin at intervals of 4 weeks after an episode of acute rheumatic fever. Inadvertently, he had been receiving only one-third of the appropriate dose and was readmitted to hospital nearly 32 weeks after his first attack with an exacerbation of his rheumatic fever and with obvious carditis. The pattern of anti-MAP titres observed in relation to other streptococcal serology is shown in fig. 3 .

Five other rheumatic fever subjects had recurrences during the study. A lack of serum samples in the interval between follow-up of the first attack and recurrence made it difficult to interpret the results. However, it was apparent that a high MAP I antibody response during the primary attack did not necessarily result in a high or higher response on recurrence. One patient, for example, had a peak anti-MAP I titre of 160 during her primary attack and, during a recurrence 18 months later, the peak titre was only 20. 

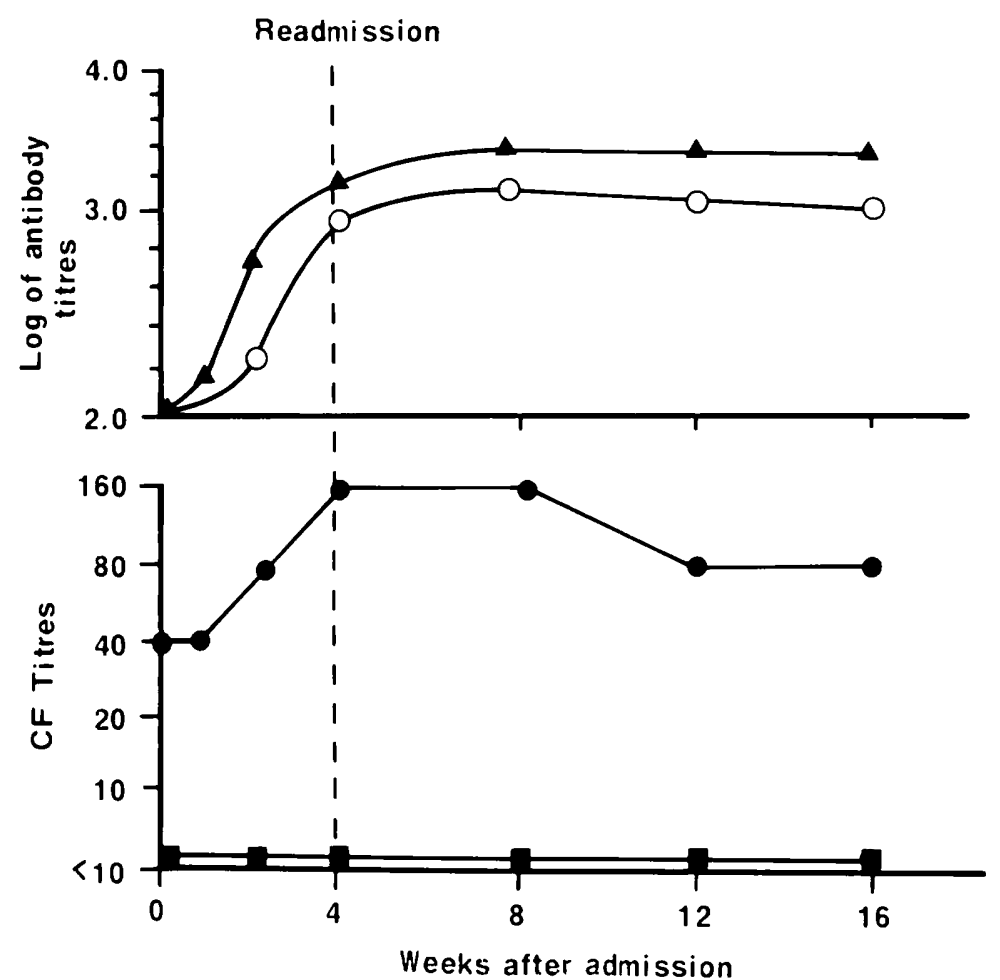

FIG. 2.-Streptococcal antibody titres in the serum of a rheumatic fever case (patient A).

MAP I; — $=$ anti-MAP II; $\mathrm{O}-\mathrm{O}=\mathrm{ASO} ;-\triangle=$ anti-DNAase $\mathrm{B}$.

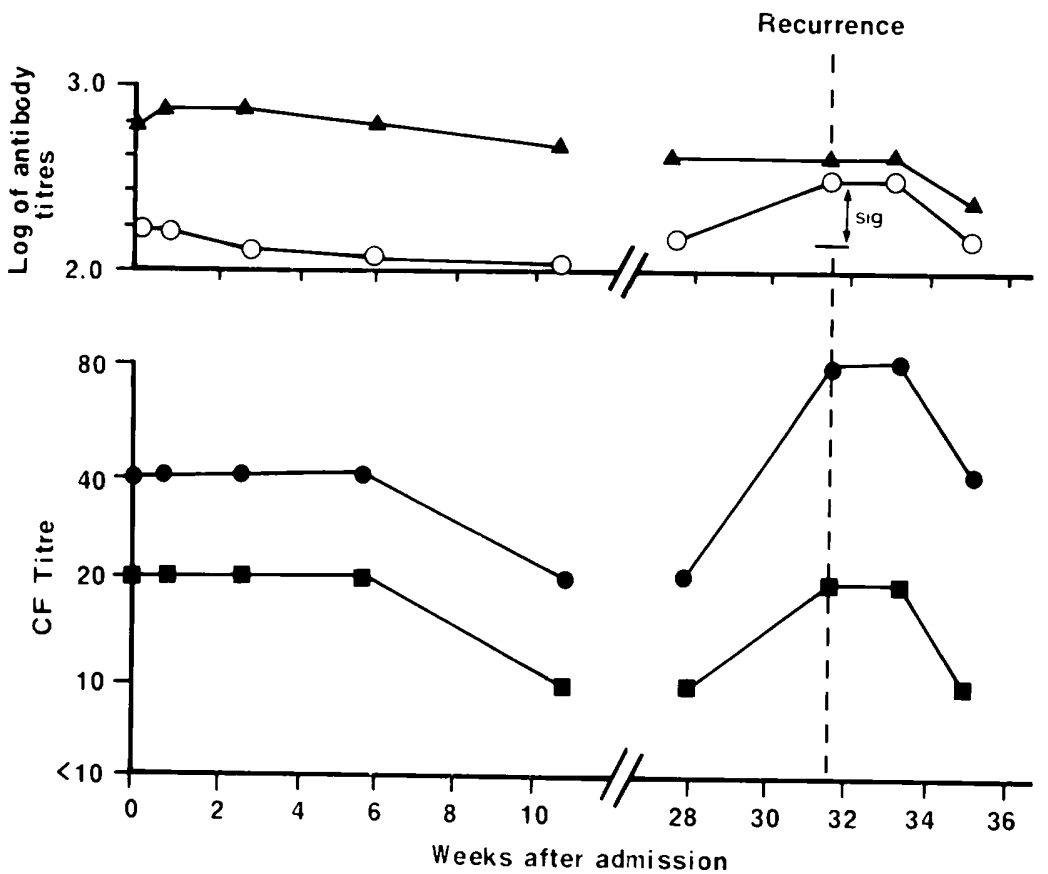

FIG. 3.- Streptococcal antibody titres in the serum of a rheumatic fever case (patient B). MAP I; - anti-Map II; $O-O=A S O ;-\Lambda=a n t i-D N A a s e ~ B$. 


\section{Anti-MAP titres of rheumatic fever subjects compared with} matched controls and patients with acute glomerulonephritis

Anti-MAP titres for four matched controls could not be interpreted because of anti-complementary activity, despite absorption with complement. Thus, results for 46 rheumatic fever subjects and their controls were compared. Whereas 31 of 46 $(67 \cdot 4 \%)$ rheumatic fever subjects had anti-MAP I titres $>40$, only $10(21 \cdot 7 \%)$ of the control group had such titres (fig. 4). This difference was highly significant $\left(\chi^{2}=19 \cdot 80\right.$, $\mathrm{p}<0.001)$. The distribution of antibody titres to the MAP II antigen was similar in both groups. The variation in anti-MAP I titres might reflect the difference between individuals who had had recent streptococcal infection (rheumatic fever subjects) and a control group amongst whom a limited number had evidence of recent streptococcal infection; therefore, anti-MAP I titres of the rheumatic fever subjects were also compared with those found in a matched group of patients with acute post-streptococcal glomerulonephritis. Twenty-one glomerulonephritis subjects could be matched with rheumatic fever individuals (fig. 4). Only four $(19.0 \%)$ glomerulonephritis subjects had titres $>40$ compared with $14(66 \cdot 6 \%)$ rheumatic fever subjects $\left(\chi^{2}=9 \cdot 82\right.$, $\mathrm{p}<0.01)$.

\section{Anti-MAP titres of normal children relative to age}

To investigate whether the peak anti-MAP I titres recorded at admission were either influenced by a history of repeated streptococcal infection or represented an
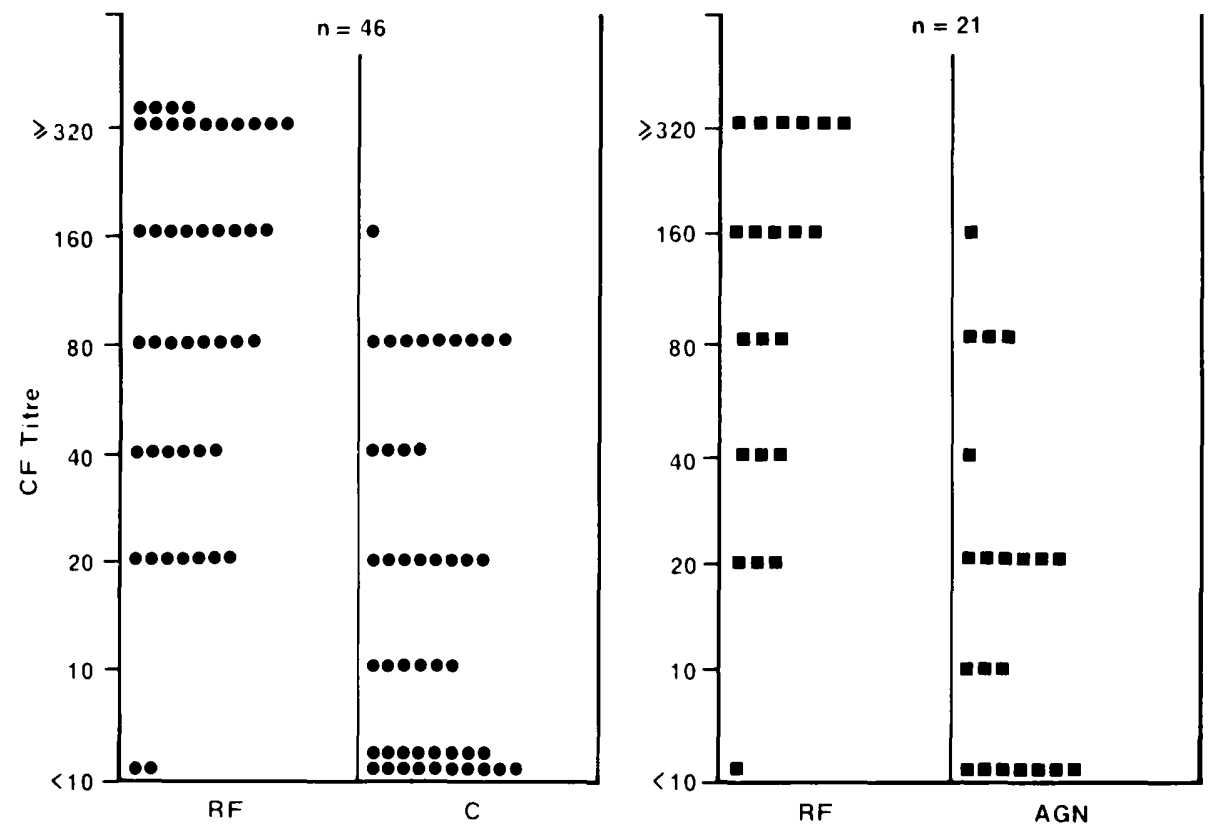

FIG. 4.-Titres of anti-MAP I in sera of comparative groups; $\bullet=$ RF subjects and matched controls; $\boldsymbol{\square}=\mathrm{RF}$ subjects and matched acute glomerulonephritis cases. 
antibody response to immediate past infection, we estimated the anti-MAP titres in the serum of 89 children who were not known to have had recent exposure to streptococci. These children were selected by the criterion that neither ASO nor anti-DNAase B levels were elevated above the upper limit of normal for their age group. Cumulative percentage values for the anti-MAP I and anti-MAP II titres of sera from these children were determined for each age group (fig. 5). Similar curves were obtained for the 6-10 and 11-15 age groups. A lower level of residual antibody was found in 2-5-year-old children, but the sample size (15 children) was small.

The cumulative frequency distribution of MAP I antibody titres in rheumatic fever and control subjects was compared for each age group. The cumulative frequency distribution was transformed into probits and the probit means compared. The results showed that for each age group the probit mean was significantly higher for the rheumatic fever group (table II). However the 2-5-year-old group contained only six pairs of titres.

\section{Discussion}

It has been suggested that most rheumatic fever individuals consistently differ from others in having high serum levels of anti-MAP I antibody at the time of their rheumatic episode (Widdowson et al., 1971). This response may reflect stimulation by streptococcal serotypes possessing the MAP I antigen (Widdowson et al., 1976). Thus there is a strong suggestion that rheumatogenic serotypes may be found among the opacity factor-negative MAP I serotypes that invade the throat. In the present study, $68 \%$ of rheumatic fever subjects had complement-fixing antibody to the MAP I antigen
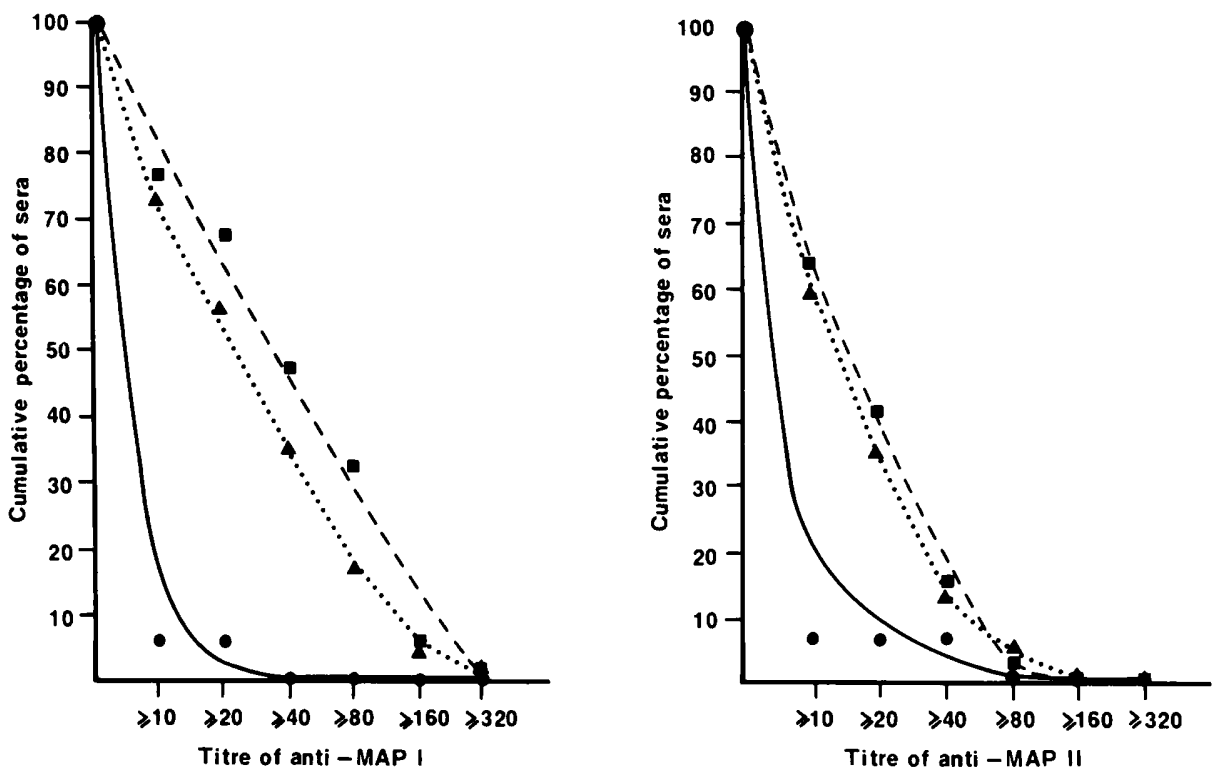

FIG. 5.-Plots of cumulative percentage values for the anti-MAP I and anti-MAP II titres of sera from normal children divided by age group: $-\longrightarrow$ age $2-5$ years; $\triangle \ldots .$. age $6-10$ years; $\square-\ldots$ age 11-15 years. 
TABLE II

Comparison of probit means obtained from transformed frequency distributions of MAP I antibody titres for rheumatic fever and control subjects considered by age-group

\begin{tabular}{|c|c|c|c|c|}
\hline \multirow[b]{2}{*}{ Age group (years) } & \multirow{2}{*}{$\begin{array}{l}\text { Subject } \\
\text { group }\end{array}$} & \multirow{2}{*}{$\begin{array}{l}\text { Probit } \\
\text { mean }\end{array}$} & \multicolumn{2}{|c|}{$\begin{array}{l}\text { Difference in } \\
\text { probit mean }\end{array}$} \\
\hline & & & $t^{*}$ & $\mathrm{p}$ \\
\hline $2-5(n=6)$ & $\left\{\begin{array}{l}R F \\
C\end{array}\right.$ & $\left.\begin{array}{l}63.88 \\
13.87\end{array}\right\}$ & $3 \cdot 2$ & $<0.05$ \\
\hline $6-10(n=23)$ & $\left\{\begin{array}{l}\mathrm{RF} \\
\mathrm{C}\end{array}\right.$ & $\left.\begin{array}{l}73.92 \\
21.00\end{array}\right\}$ & $5 \cdot 23$ & $<0.005$ \\
\hline $11-15(n=17)$ & $\left\{\begin{array}{l}\mathrm{RF} \\
\mathrm{C}\end{array}\right.$ & $\left.\begin{array}{l}71 \cdot 55 \\
29 \cdot 40\end{array}\right\}$ & $2 \cdot 73$ & $<0.05$ \\
\hline
\end{tabular}

$\mathrm{RF}=$ rheumatic fever subjects; $\mathrm{C}=$ control subjects

* Student's T test

with titres exceeding 40. Two subjects had no detectable anti-MAP I antibody but exhibited raised anti-MAP II antibody titres. Widdowson et al. (1971) reported 20 rheumatic fever cases, all of whom had titres $>60$, and Beachey et al. (1973) found $58.6 \%$ of their rheumatic fever cases had titres of non-type-specific $\mathrm{M}$ antibody $\geqslant 40$.

Widdowson et al. (1976) found sera that fixed complement with $\mathrm{M}$-antigen preparations of opacity factor-positive types and not of opacity factor-negative types 'rare' amongst the sera they studied. Taking a titre $>40$ as an arbitrary level of significance for MAP II antibody, only two subjects in the present study had significantly raised titres. However in one case the anti-MAP I antibody titre was even higher. Since we began measuring both MAP antibodies in our laboratory, only six $(4 \%)$ of 152 sera from individuals with evidence of recent streptococcal infection, have exhibited an anti-MAP II antibody titre $>40$ when the anti-MAP I antibody titre was $<40$. Five of the six individuals were being investigated for acute post-streptococcal glomerulonephritis (unpublished data).

Titres of MAP antibodies did not increase after admission to hospital in 40 of our 50 rheumatic fever subjects. However pre-infection or pre-admission sera are not usually available for such cases. We assume, therefore, that the increase in antibody titres occurred before admission, or that no change was initiated by the streptococcus responsible for the episode of rheumatic fever. Sequential studies showed that titres of anti-MAP could be maintained for prolonged periods and that any decrease was independent of decreases in ASO and anti-DNAase B antibodies. In some individuals, MAP antibody titres returned to very low titres. Recurrence of rheumatic fever did not always result in a return to high titres of MAP antibody. However, this could be due to modification of the antibody response by antibiotic therapy. Responses to the type-specific $M$ antigens have been shown to be modified by prompt therapy of upper respiratory tract infection (Siegel, Johnson and Stollerman, 1961; Guirguis et al., 1982).

Cross-reactions between MAP I and MAP II antigens have been reported (Widdowson et al., 1976). These workers showed that a small rise in the MAP II titre accompanied increases in MAP I titres. We also demonstrated parallel antibody activity. 
Upper limits of normal for the streptococcal antibodies, ASO and anti-DNAase B, have been shown to increase with age during childhood (Ayoub and Wannamaker, 1962). In our group of normal children, MAP antibody titres in the 6-10- and 11-15-year-olds were very similar and were distinctly higher than in the 2-5-year group. However, in all age groups, titres of MAP I antibody were significantly higher in rheumatic fever subjects than in controls.

The relationship of anti-MAP titres to the serotype of the infecting streptococcus has been investigated by others (Widdowson et al., 1974; Widdowson et al., 1976). It was not possible to investigate such a correlation in the present study. However one rheumatic fever subject, from whose throat a streptococcus of serotype M5 was isolated at the time of admission to hospital, developed high titres of M-type 5 specific antibodies and exhibited an elevated anti-MAP I titre. Retrospective studies of M antibodies in the same rheumatic fever patients have revealed that significantly more had serum levels of M5 and M52 type-specific antibodies than did matched controls (Martin, unpublished data). Streptococcus serotype M5 is thought to possess a MAP I antigen and, although serotype M52 was initially described as MAP variable by Widdowson et al. (1976), it was subsequently categorised as a MAP I type (Widdowson, 1980). Whether the titres obtained in this study reflect immediate or previous exposure to these particular serotypes is not known.

This work was supported by a project grant from the Medical Research Council of New Zealand for which the authors are particularly grateful. We wish also to acknowledge the contribution of Doctors D. M. J. Barry, K. P. Dawson, D. R. Lennon and M. R. Miles, Paediatricians, in providing material from patients. Statistical advice was given by Dr J. Rankin, M.R.S.U., Department of Health, Wellington. This paper is published with the authority of the Director-General of Health, Department of Health, Wellington, New Zealand.

\section{REFERENCES}

Ayoub E M, Wannamaker L W 1962 Evaluation of the streptococcal desoxyribonuclease B and diphosphopyridine nucleotidase antibody tests in acute rheumatic fever and acute glomerulonephritis. Pediatrics 29:527-538.

Beachey E H, Ofek I, Bisno A L 1973 Studies of antibodies to non-type-specific antigens associated with streptococcal M protein in the sera of patients with rheumatic fever. Journal of Immunology 111:1361-1366.

Dawson K P, Martin D R 1982 Streptococcal involvement in childhood acute glomerulonephritis: a review of 20 cases at admission. New Zealand Medical Journal 95:373-376.

Guirguis N, Fraser D W, Facklam R R, El Kholy A, Wannamaker L W 1982 Type-specific immunity and pharyngeal acquisition of group A streptococcus. American Journal of Epidemiology 116:933-939.

Liao S J 1951 A modification of the antistreptolysin test. Journal of Laboratory and Clinical Medicine 38:648-659.

Nelson J, Ayoub E M, Wannamaker L W 1968 Streptococcal anti-deoxyribonuclease B: microtechnique determination. Journal of Laboratory and Clinical Medicine 71:867-873.

Siegel A C, Johnson E E, Stollerman G H 1961 Controlled studies of streptococcal pharyngitis in a pediatric population. 2. Behaviour of the type-specific immune response. New England Journal of Medicine 265:566-571.

Vosti K L, Johnson R H, Dillon M F 1971 Further characterizaton of purified fractions of M protein from a strain of group A type 12 streptococcus. Journal of Immunology 107: 104-114.

Wannamaker L W, Ayoub E M 1960 Antibody titers in acute rheumatic fever. Circulation $21: 598-614$. 
Widdowson J P 1980 The M-associated protein antigens of group A streptococci. In: Read S E, Zabriskie J B (eds) Streptococcal disease and the immune response, Academic Press, New York, pp 125-147.

Widdowson J P, Maxted W R, Notley C M, Pinney A M 1974 The antibody responses in man to infection with different serotypes of group-A streptococci. Journal of Medical Microbiology 7:483-496.

Widdowson J P, Maxted W R, Pinney A M 1971 An M-associated protein antigen (MAP) of group A streptococci. Journal of Hygiene, Cambridge 69:553-564.

Widdowson J P, Maxted W R, Pinney A M 1976 Immunological heterogeneity among the $\mathrm{M}$-associated protein antigens of group-A streptococci. Journal of Medical Microbiology 9:73-88. 